\title{
EDITORIAL
}

\section{Sobre a Memória e o esquecimento}

Reinaldo dos Santos Barroso Junior

Não poderia haver melhor frase para iniciar este número da revista Outros Tempos - Pesquisa em Foco que a frase de Milan Kundera em $O$ livro do riso e do esquecimento de 1981: "A luta do homem contra o poder é a luta da memória contra o esquecimento". Neste número temos o orgulho de apresentar o dossiê História e Memória no qual são veiculados oito artigos que utilizaram o conceito de memória em seus trabalhos. Trabalhos como o de Jayme Ribeiro que percebe a utilização da memória acerca da Bomba Atômica por partes dos comunistas e dos não comunistas, ou, ainda, de Sonia Maria de Meneses problematizando as relações entre mídia, memória e esquecimento. Já os trabalhos de Carolina Cunha e Raquel França dos Santos Ferreira, examinam o acervo documental escrito, a primeira perscrutou as Memórias do frei dominicano Servando Teresa de Mier na tentativa de entender o ideário iluminista, enquanto a segunda examinou as crônicas de Antonio Maria, compositor e produtor pernambucano, para entender o imaginário carioca da década de 1950. Já Daniel Choma analisa não os escritos de determinado personagem, mas o acervo fotográfico de Armínio Kaiser, enquanto Rafael Hansen Quinsani analisa a memória a partir do filme Soldados de Salamina, de 2003. Fábio da Silva Souza, por sua vez, analisa a história e a memória da famigerada Revolução Mexicana, e Leonardo da Costa Ferreira discute a memória de luta política de Amadeu Amaral.

Para completar o Dossiê de História e Memória temos a transcrição de um documento cedido e comentado pela professora Júlia Constança Pereira Camêlo, na realidade, uma entrevista concedida em 1996, por Onofre Alves de Siqueira, o Bebelo, à Cléa Camêlo de Albuquerque, referente às Ligas Camponesas. E, por fim, uma entrevista com a historiadora e pesquisadora Ana Maria Mauad, responsável pelo Laboratório de História Oral e Imagem da Universidade Federal Fluminense.

Na seção livre, com artigos dos mais diversos assuntos, vocês leitores podem encontrar o artigo de Maria Regina Santos de Souza evidenciando as dificuldades enfrentadas por viúvas na petições de pensão de seus maridos mortos na Guerra do Paraguai, ou, ainda, o trabalho de Marili Peres Junqueira enfocando as relações diplomáticas entre Brasil e Itália no final do século XIX. Thiago Cavaliere Mourelle, discute as origens do trabalhismo através do interventor Pedro Ernesto. No artigo em co-autoria de Valter 
Fernandes e Victor Abril poderão encontrar ainda uma discussão sobre a complexa relação de poder existente no império português a partir do Rio de Janeiro.

O desfecho dos artigos esta por conta da antropóloga italiana Anna Casella Paltrinieri com o texto intitulado Imigração, raça e cultura: o ensinamento de Franz Boas publicado na revista italiana Quaderni del Premio Letterario Giuseppe Acerbi, em novembro de 2008, e traduzido, para essa edição, pelos professores Claúdio Zannoni e Maria Mirtes dos Santos Barros.

Além dos artigos os leitores poderão encontrar, ainda, duas resenhas: a primeira do historiador Rogério Chaves da Silva do livro História Viva - Teoria da História III: formas e funções do conhecimento histórico, do historiador alemão Jorn Rusen; e a segunda, de Régia Agostinho da Silva, sobre a obra Uma escritora na periferia do império: vida e obra de Emília Freitas, escrita por Alcilene Cavalcante.

Como podem observar, esse número está quase que exclusivamente dedicado à Memória, e a maior parte das colaborações surgiu a partir de historiadores, contudo, isso não significa dizer que esquecemos os outros pesquisadores e escritores acadêmicos, o espaço está aberto para todas as contribuições e continuamos aguardando seus trabalhos.

A todos, boa leitura! 